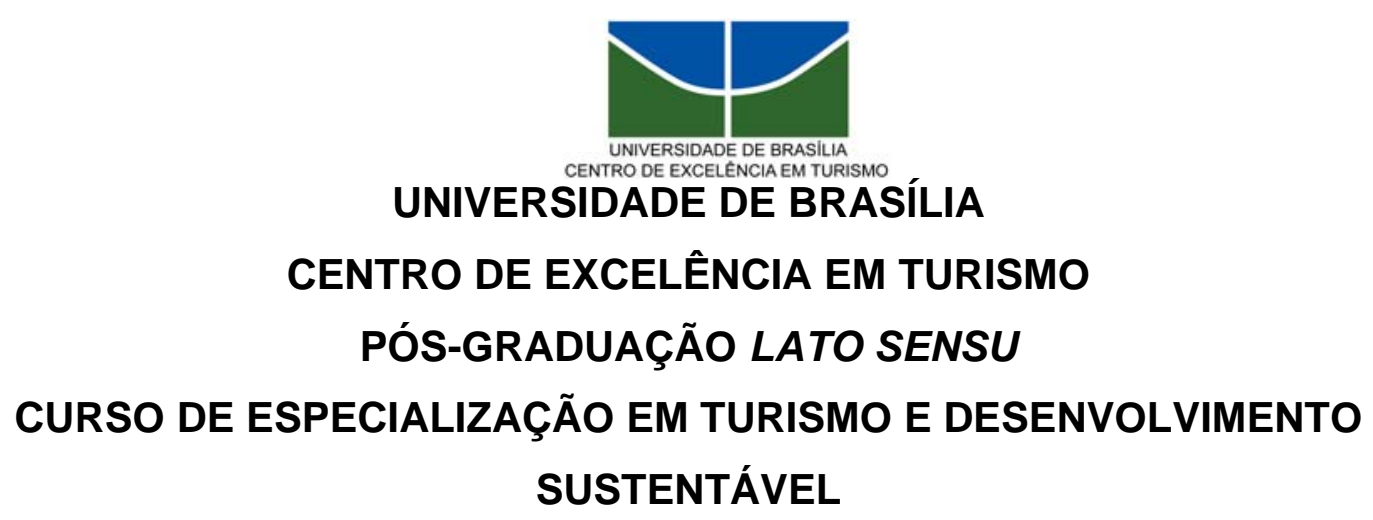

ESPAÇO CULTURAL COMO ATRATIVO TURÍSTICO

FRANCISCO FLAVIO EMERY DE SOUZA FILHO

BRASÍLIA 
FRANCISCO FLAVIO EMERY DE SOUZA FILHO

ESPAÇO CULTURAL COMO ATRATIVO TURÍSTICO

Monografia apresentada ao Centro de Excelência em Turismo - CET, da Universidade de Brasília - UnB, como requisito parcial à obtenção do grau de Especialista em Turismo e Desenvolvimento Sustentável.

Dra lara Lúcio Gomes Brasileiro.

\section{BRASÍLIA}




\title{
ESPAÇO CULTURAL COMO ATRATIVO TURÍSTICO
}

\author{
Por
}

\section{FRANCISCO FLAVIO EMERY DE SOUZA FILHO}

Aprovado por:

Presidente: Dra. Iara Lúcia Gomes Brasileiro

Membro: Msc. Ariadne Pedra Bittencourt .

Membro: Dra. Ellen Fensterseifer Woortmann .

Brasília, 18 de junho, 2007. 
Filho, Francisco Flávio E. de Souza.

Espaço Cultural como Atrativo Turístico

Francisco Flávio Emery de Souza Filho - Brasília, 2007.

Monografia (especialização) - Universidade de Brasília.

Centro de Excelência em Turismo, 2007.

Orientador: Dra. Iara Lúcio Gomes Brasileiro

1. Turismo. 2. Cultura. 3. Espaço Cultural I. Título.

II. Título: Espaço Cultural como Atrativo Turístico. 


\section{AGRADECIMENTOS}

Agradeço a todos aqueles que colaboraram para a elaboração desse trabalho, aos professores e a orientadora Dra. Iara Brasileiro e principalmente à minha colega Marcionila Sames. 
Dedico este trabalho ao meu filho Antônio 


\section{RESUMO}

O presente estudo tem como objetivo abordar a importância de um espaço cultural como atrativo turístico. O estudo foi baseado em revisão de literatura sobre o tema. A cultura é um elemento de integração de um povo e deve estar na pauta política como fundamental para a formação e o desenvolvimento individual e social, levando a processos de geração de emprego e renda. a cultura brasileira tem uma grande riqueza manifestada de diversas formas, e essa criatividade exerce fascínio sobre as pessoas e instituições. Sendo assim, se começarem a surgir projetos bem estruturados sobre turismo cultural poderá haver um avanço rumo à responsabilidade social.

PALAVRAS-CHAVE: Turismo; Cultura; Espaço Cultural. 


\begin{abstract}
The present study it has as objective to approach the importance of tourist a cultural space as attractive. The study it was based on revision of literature on the subject. The culture is an element of integration of a people and must be in the guideline politics as basic for the formation and the individual and social development, taking the processes of generation of job and income. The Brazilian culture has a great revealed wealth of diverse forms, e this creativity exerts allure on the people and institutions. Being thus, if to start to appear well structuralized projects on cultural tourism will be able to have an advance route to the social responsibility.
\end{abstract}

WORDS KEY: Tourism; Culture; Cultural space. 


\section{LISTA DE FIGURAS}

Figura 1: As diversas dimensões do evento no turismo cultural. 18

Figura 2: Os diversos papéis no contexto do desenvolvimento e preservação do patrimônio cultural 19

Figura 3: Triângulo de Sustentação Econômica da Produção Cultural 21

Figura 4: Foto do Espaço Cultural 508 Sul. 31 


\section{SUMÁRIO}

INTRODUÇÃO

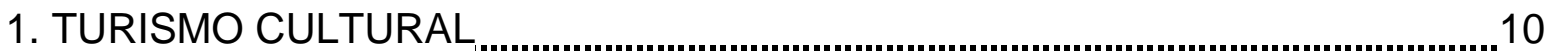

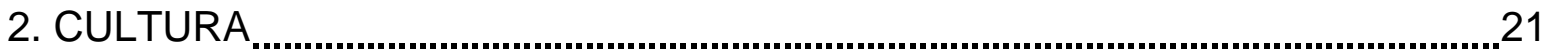

2.1. PRODUÇÃO CULTURAL ................................................................................ 21

2.2. LEIS DE INCENTIVO À CULTURA .................................................................24

2.3. RESPONSABILIDADE SOCIAL E CULTURAL ...............................................2

3. O ESPAÇO CULTURAL COMO ATRATIVO TURÍSTICO .....................................30

CONCLUSÃO

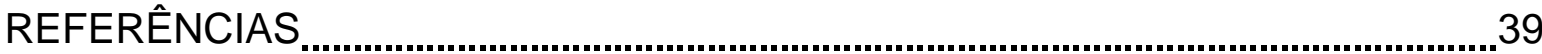

ANEXO 1: MAPAS DO ESPAÇO CULTURAL 508 SUL .............................................41

ANEXO 2: ESPAÇOS DO ESPAÇO CULTURAL 508 SUL

ANEXO 3: EVENTOS DO ESPAÇO CULTURAL 508 SUL ....................................48

ANEXO 4: NOMES QUE DEFINEM O ESPAÇO CULTURAL 508 SUL....................54 


\section{INTRODUÇÃO}

A cultura é um elemento de integração de um povo e deve estar na pauta política como fundamental para a formação e o desenvolvimento individual e social, levando a processos de geração de emprego e renda.

Constitui-se num poderoso instrumento de transformação e de inclusão social, em qualquer tempo e lugar, promovendo o desenvolvimento do espírito crítico necessário ao exercício pleno da cidadania.

Tendo em vista a importância da cultura, tornou-se interessante realizar este estudo sobre a importância do espaço cultural como atrativo turístico, Desse modo, abre-se uma excelente oportunidade de vincular ações culturais que atendam às expectativas da comunidade e que, ao mesmo tempo, atendam as necessidades do município de movimentar a atividade turística, que proporciona emprego e renda para a região.

Neste contexto, o presente estudo tem como objetivo abordar a importância de um espaço cultural como atrativo turístico.

A cultura brasileira tem uma grande riqueza manifestada de diversas formas, e essa criatividade exerce fascínio sobre as pessoas e instituições. Sendo assim, se começarem a surgir projetos bem estruturados sobre turismo cultural poderá haver um avanço rumo à responsabilidade social.

O trabalho será fundamentado a partir de revisão de literatura sobre o tema, tendo como foco do estudo o espaço cultural localizado no Distrito Federal. Trata-se de uma pesquisa básica que objetiva explorar conhecimentos úteis para o avanço da ciência sem aplicação prática prevista. Quanto à abordagem dos dados, estes serão tratados de forma qualitativa. De acordo com Lakatos e Marconi (2004), a pesquisa 
qualitativa pode ser caracterizada como a tentativa de uma compreensão detalhada de significados e características situacionais.

Em relação ao objetivo temos uma pesquisa explicativa: visa identificar os fatores que determinam ou contribuem para a ocorrência dos fenômenos. Aprofunda o conhecimento da realidade porque explica a razão, o "porquê" das coisas (Lakatos; Marconi, 2004).

Do ponto de vista dos procedimentos técnicos a revisão de literatura será baseada em pesquisa bibliográfica sobre o tema. A pesquisa bibliográfica é elaborada a partir de material já publicado, constituído principalmente por livros, artigos de periódicos e atualmente com material disponibilizado na Internet, todos devidamente citados. 


\section{TURISMO CULTURAL}

Segundo a Embratur (2000) o turismo é uma das atividades sócioeconômicas de maior importância em vários paises do mundo, chegando a ser a de maior ênfase em muitos deles. Vendo essa importância, podemos afirmar que esse fenômeno de deslocamento voluntário e temporário deve ser visto e estudado com muita atenção para que não ocorram choques culturais, naturais, políticos, sociais e econômicos nos centros receptores.

Segundo Andrade (2003, p. 98), turismo pode ser entendido como: "Complexo de atividades e serviços relacionados aos deslocamentos, transportes, alojamentos, alimentação, circulação de produtos típicos, atividades relacionadas aos movimentos culturais, visitas, lazer e entretenimento". Esse conceito enfatiza um tópico importante: atividades que compõem o turismo.

O fenômeno turístico não poderia acontecer se não houvesse outros serviços para auxiliá-lo. Um exemplo disso é a hotelaria. Sem os meios de hospedagem não haveria como os turistas se alojarem nos lugares visitados. Outro exemplo ainda mais prático são os meios de transportes, já que sem eles não haveria como os indivíduos se deslocarem até os centros receptores escolhidos.

Segundo Beni (2003, p. 37), "o turismo pode identificar-se em três tendências para a sua definição: a econômica, a técnica e a holística". Então, conclui-se que se deve formar um conceito com estas três tendências, para que haja um conceito comum entre todos os que estudam o mesmo. Os conceitos acima mostram como o turismo é complexo, já que lida com motivações, viagens, diferentes culturas e ainda vários segmentos de turistas. Com isso, o turismo deve 
ser estudado como um todo e não apenas em partes, para que se chegue a um possível conceito aceito por todos.

São vários os elementos que influenciam o turista a adquirir um determinado produto turístico oferecido. Abaixo estão alguns destes elementos: o preço; a distância até o centro receptor; o tipo de transporte; marketing; desejo e necessidade de evasão; busca de descanso; lei da substituição.Esses são alguns dos vários fatores influenciadores que fazem o turista escolher um centro receptor ao invés de outro. A análise dos mesmos é dada abaixo, segundo Beni (2003):

a) O preço: é o principal deles, principalmente no turismo de massa. O turismo de massa é composto basicamente pela classe média assalariada e empresários de pequeno e médio porte. Eles não possuem uma renda mensal que dê para que saiam gastando com tudo que vêm pela frente sem analisar antes os preços. Por isso comparam bem os preços antes de comprar o produto.

b) Distância até o centro receptor: quanto maior a distância maiores serão os preços no que se refere aos meios de transporte. No momento de adquirir um produto turístico, o indivíduo pode preferir viajar para um lugar menos distante para economizar nas despesas e com isso sobrar mais dinheiro para a viagem ou até mesmo para adquirir um outro tipo de produto (televisão, ventilador, aparelho de som etc.). Para o Brasil, uma opção sensata seria, e será segundo pesquisa da organização mundial do turismo (OMT, 2000), investir nos países que constituem o 
MERCOSUL. Não só a estes países em especial devem ser dada ênfase, mas qualquer um que se situe o mais próximo possível, já que as distâncias serão menores e conseqüentemente (não em todos os casos) o preço será menor.

c) Tipo de transporte: com o passar dos anos os meios de transportes têm evoluído muito com o avanço da tecnologia. Todos os meios de transportes, aéreos, terrestres e aquáticos ganharam uma maior dinâmica e também um maior conforto a oferecer a seus usuários. Com essa evolução ficou muito mais fácil viajar, já que com esse avanço os deslocamentos a grandes distâncias ficaram bem mais rápidos. Um exemplo disso é o transporte aéreo. Pode-se viajar com conforto e "segurança" saindo de um país a outro em algumas horas.

d) Marketing: segundo a EMBRATUR (2000), marketing turístico é o conjunto de técnicas estatísticas, econômicas, sociológicas e psicológicas, utilizadas para estudar e conquistar o mercado, mediante lançamento planejado dos produtos, consistindo numa estratégia dos produtores para adequar seus recursos às novas oportunidades que o mercado oferece. O turista só pode tomar conhecimento de um produto turístico se houver uma boa estratégia de marketing. Essas estratégias 
influenciam o indivíduo a adquirir certo produto, como exemplo, um pacote em uma agência. Através do conceito exposto, entende-se que marketing turístico são simplesmente técnicas para induzir uma pessoa a comprar um certo produto. Assim sendo, ele é um forte influenciador na hora de adquirir um produto turístico. $\mathrm{O}$ homem nos dias atuais é dono de informações sobre o que acontece no mundo com bem mais facilidade. Através dos meios de comunicação de massa (TV, radio, jornais etc.) ele pode ter acesso a muitas informações sem necessariamente possuir um nível de escolaridade elevado. Para Leite (1987, p. 73-74): "Ao mesmo tempo que se mantém mais informado, mais atualizado, ampliando os seus horizontes culturais, passou a ter uma crescente curiosidade a respeito das belezas naturais, das tradições, das antigas civilizações,...". Portanto, concluí-se que, a propaganda em seus meios de propagação, junto com aumento do interesse pela cultura da população, influencia os indivíduos a terem o desejo de conhecer lugares por eles ainda não vistos.

e) Desejo e necessidade de evasão: o homem é um ser inquieto por natureza e por isso precisa se deslocar para realizar esses desejos. Vendo esse fato conclui-se que o turismo é uma boa opção para a realização desse desejo, já que o individuo vai se deslocar para lugares de sua 
f) Busca de descanso: nos dias atuais, com uma intensa urbanização e desenvolvimento de novas tecnologias, o homem encontra-se ao longo dos dias com um intenso cansaço físico e também mental. Esse indivíduo que passa todos os dias num trabalho estressante e rotineiro precisa de um tempo livre (férias, finais de semana e feriados prolongados) para viajar e conseguir descansar.

g) Lei da substituição: muitas vezes um indivíduo que planeja uma viagem após economizar o bastante para adquirir um pacote em uma agencia qualquer, se depara com algumas situações bastante incômodas: o carro quebrou, o ar-condicionado queimou, a geladeira está velha demais. A pessoa prefere consertar ou comprar um bem diferente de um pacote turístico, pois será, no momento, de maior utilidade do que uma viagem.

O turismo é uma atividade econômica que precisa de uma mão-de-obra bastante intensa e que demanda qualificação. Assim, é um forte gerador de empregos. Além disso, movimenta e impulsiona a produção de 52 atividades dinamizadas no Brasil, desde a produção de cadeiras para restaurante até a construção de um hotel.

O turismo cultural é o segmento do turismo que trata das viagens de estudo, um item importante na pauta de alguns países, sobretudo de língua inglesa, como a Grã-Bretanha e os Estados Unidos, podemos citar também, as cidades de Barcelona 
e Bilbao que são destinos turísticos por seus atrativos culturais.

A cultura não se restringe ao estudo formal, mas sim: todas as ações que fazem parte da cultura.

O turismo voltado para a cultura de uma região, tende a considerar o patrimônio cultural como aquele que se volta para certos tipos de atividades mais propriamente "culturais", tais como as visitas a museus, a cidades históricas ou a roteiros temáticos. Este é um aspecto importante do turismo moderno, pois os maiores países, regiões e cidades receptoras de turistas podem ser identificados como destinos de visitantes ávidos por cultura, como é o caso da Itália, o país com o maior número de patrimônios tombados pela Unesco, mas também da França, Egito, Grécia, Turquia e Grã-Bretanha. No Brasil, este é o caso das cidades coloniais de Minas Gerais e das missões jesuíticas no Sul.

No turismo cultural, ainda que a política de patrimônio tenha preservado muito desigualmente os bens culturais, com o predomínio do grandioso e rebuscado em detrimento daquilo que representava os costumes e anseios de muitos, não cabe dúvida de que o contato direto com museus, edifícios e artefatos históricos permite uma salutar abertura para a variedade cultural, no passado e no presente.

O turismo cultural, atualmente, implica não apenas a oferta de espetáculos ou eventos, mas também a existência e preservação de um patrimônio cultural representado por museus, monumentos e locais históricos. Além do valor cultural específico, do ponto de vista do turismo cultural, esses bens materiais possuem outro valor, o de serem objetos indispensáveis, cujo consumo constitui a base de sustentação da própria atividade. O mesmo acontece com o patrimônio ambiental, cuja valorização ultrapassa sua importância para qualidade de vida das populações locais (Rodrigues, 2005). 
Cidades como Londres, Paris e Nova York recebem grande número de turistas, nacionais e estrangeiros, em todas as épocas do ano. Ao lado de testemunhos arquitetônicos, parques, monumentos históricos, gastronomia e possibilidades de consumo diferenciado, seus visitantes contam com uma ampla gama de museus a ser conhecida. Aliás, uma visita a Londres está, quase sempre, associada ao British Museum; ao Louvre, no caso de Paris, e ao Metropolitan Museum, em Nova York (Gomes, 2005). Essa estreita relação entre o turismo e a cultura de uma região vem sendo construída ao longo do tempo, cujos elementoschave podem ser entendidos como a existência de acervos consagrados, de um trabalho dinâmico e, finalmente, de estratégias de marketing direcionada ao turismo cultural.

É importante observar que a cultura requer circulação, produção e assimilação. Isso somente é possível mediante estímulo à produção de bens culturais e à promoção de eventos. Desta forma o espaço cultural pode ser um atrativo no turismo cultural, tendo como foco o binômio patrimônio cultural-evento e cujas características são as seguintes (Melo Neto, 2005, p. 59):

a) uso da promoção de eventos como estratégia de revitalização do patrimônio histórico e cultural;

b) uso de eventos como estratégia de geração de benefícios sociais, econômicos, políticos e culturais por meio do patrimônio histórico;

c) foco no entorno das edificações tombadas como locus de realização de eventos; e

d) uso da promoção de eventos como estratégia de revitalização de espaços culturais. 
No turismo cultural um dos pontos essenciais é a realização de eventos. A realização de eventos revitaliza o conjunto do patrimônio histórico da cidade, região ou país. O uso dessa estratégia tem sido responsável pelo aumento da produção cultural (exposições, shows, cursos, palestras, venda de livros etc.), de prédios e instalações que integram o patrimônio histórico (Melo Neto, 2005).

Sob esse aspecto, o evento é visto como um agente de revitalização do valor histórico do espaço, conferindo-Ihe valor cultural. O evento também é utilizado como elemento de geração de benefícios diversos para a comunidade. Dependendo da natureza do evento (seja social, político e cultural), são gerados benefícios específicos para os habitantes e visitantes. Do ponto de vista econômico, os benefícios se traduzem em venda de ingressos, formação de grupos culturais, venda de produtos e serviços (Melo Neto, 2005).

Nesse aspecto, o evento é visto como agente de agregação de valor social, cultural, político e econômico do patrimônio histórico-cultural.

A revitalização do entorno mediante eventos traduz a outra dimensão deste como elemento de revitalização do patrimônio histórico. Ao atrair pessoas para as proximidades dos prédios históricos tombados, os eventos atraem público e estimulam a sua visita e preservação.

E, finalmente, o uso de eventos como estratégia de revitalização de conjuntos culturais. Aqui, prevalece o evento como elemento de reforço cultural e não histórico ou patrimonial (Melo Neto, 2005). 
Figura 1: As diversas dimensões do evento no turismo cultural

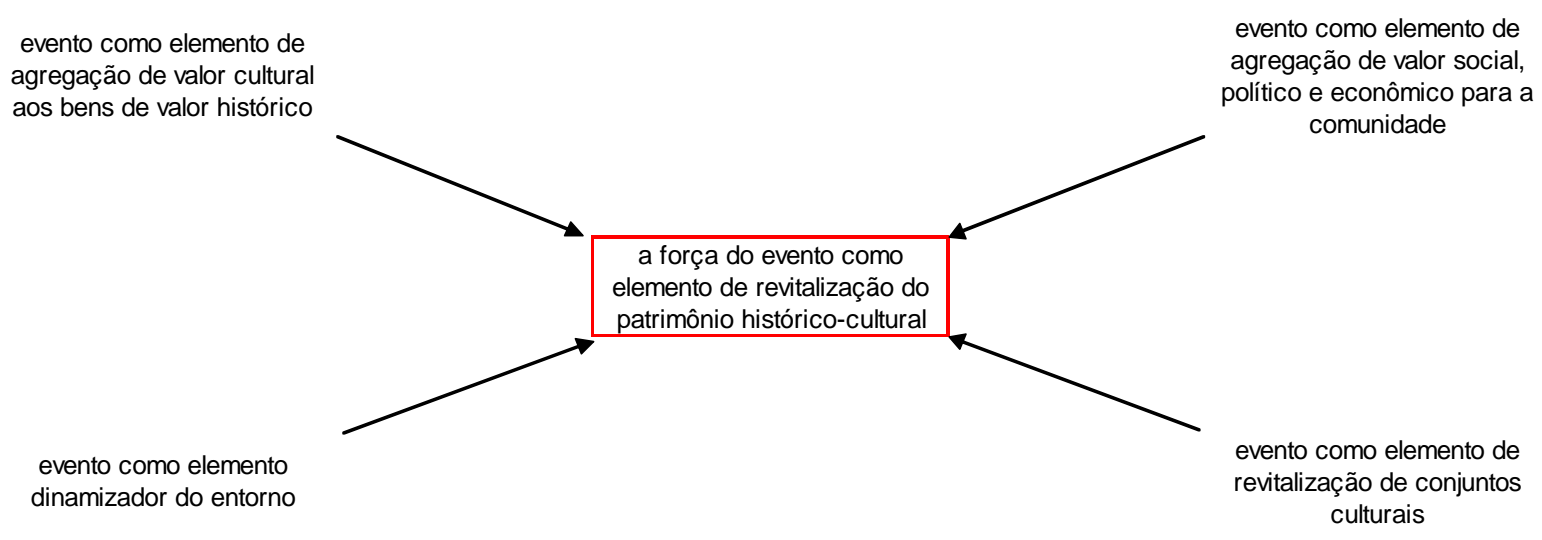

Fonte: Melo Neto, 2005, p. 60.

Ao observarmos a figura acima, verificamos que no primeiro caso, o evento surge como a 'extensão cultural' necessária para revitalizar o patrimônio histórico (evento como elemento de agregação de valor cultural aos bens de valor histórico).

No segundo, como elemento de agregação de valor social, político, cultural e econômico para a comunidade, o evento se multiplica em 'extensões diversas' (social, política, econômica e cultural) e contribui para o desenvolvimento da comunidade. Sendo realizado o evento como extensão de um bem de valor histórico e cultural, este se institucionaliza e se revitaliza no âmbito da comunidade.

O terceiro caso refere-se ao evento como elemento de revitalização de espaços ou conjuntos culturais. Nesse caso, ele promove, produz, difunde e contribui para a oferta de bens culturais. E, conseqüentemente, revitaliza e dinamiza as ações dos conjuntos culturais.

Por fim, no quarto caso, o evento como elemento de dinamização do entorno, é uma forma de revitalização do patrimônio histórico-cultural, que se baseia no aumento da atratividade do local e na sua dinamização por meio de eventos.

Os eventos podem, portanto, desempenhar papéis diversos no contexto do desenvolvimento e preservação do patrimônio cultural (Melo Neto, 2005, p. 64-65): 
a)

eventos de premiação, com o objetivo de estimular 0 aumento da produção cultural;

b)

eventos de revitalização de espaços culturais, com o objetivo de dinamizar espaços culturais;

c) eventos de atração e desenvolvimento de focos de irradiação da cultura, com o objetivo de aumentar a circulação de produtos culturais e ampliar o mercado desses produtos;

d) eventos de turismo cultural, com o objetivo de atrair novos visitantes a espaços de cultura e arte; e,

e) eventos de promoção de espaços corporativos de cultura e arte, com o objetivo de fortalecer a imagem das empresas que investem nessa área e estimular a prática do marketing de eventos por tais empresas.

Figura 2: Os diversos papéis no contexto do desenvolvimento e preservação do patrimônio cultural

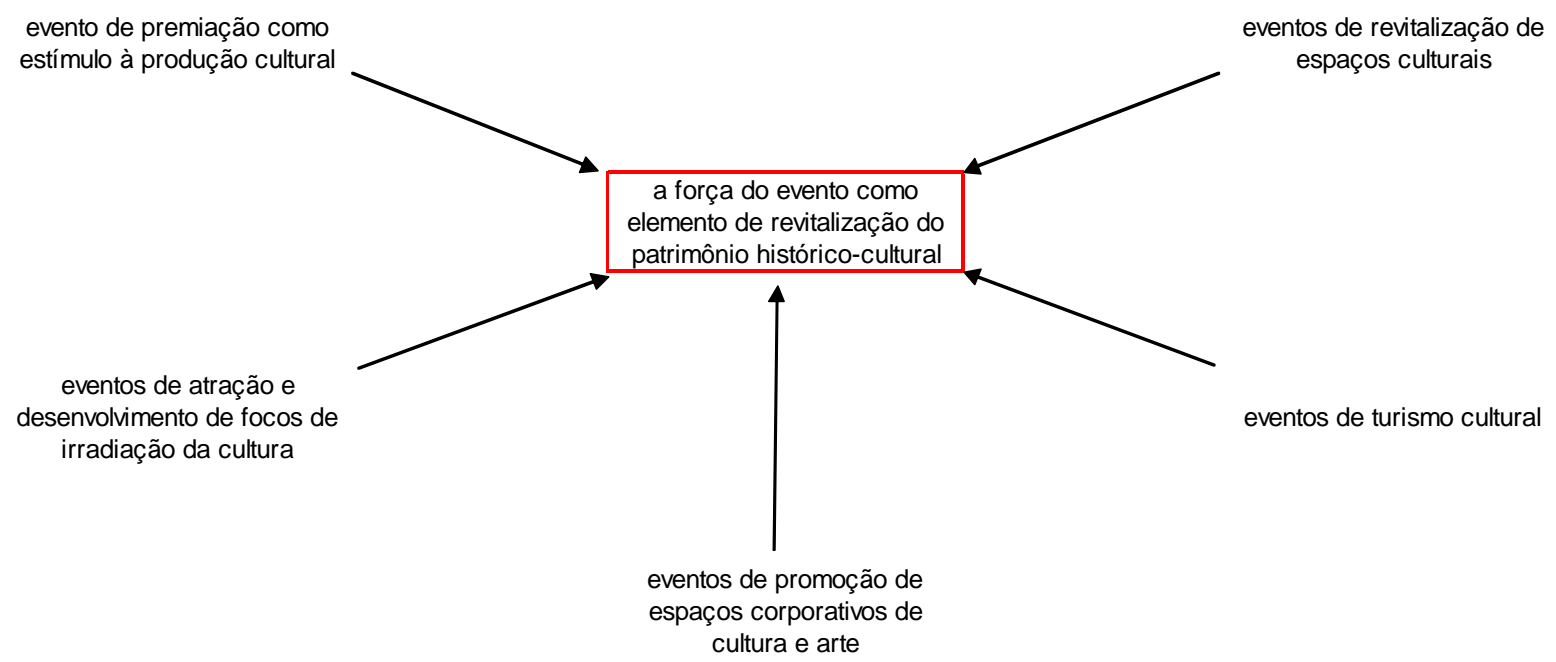

Fonte: Melo Neto, 2005, p. 65. 
Em síntese, a realização de eventos culturais é fator de suma importância no contexto turístico de uma região. O que torna o evento um agente do patrimônio histórico-cultural. 


\section{CULTURA}

\subsection{PRODUÇÃO CULTURAL}

A cultura pode ser compreendida como uma expressão coletiva para todos os modelos de comportamento adquiridos e transmitidos socialmente através de símbolos. Cultura inclui costumes, tradições e linguagem.

As formas clássicas, não só no Brasil, mas no mundo, de financiamento da produção cultural é, de um lado, o Estado (tradicional financiador), de outro a iniciativa privada e, ainda, por último, a receita direta; segundo demonstração de Almeida (1992):

Figura 3: Triângulo de Sustentação Econômica da Produção Cultural

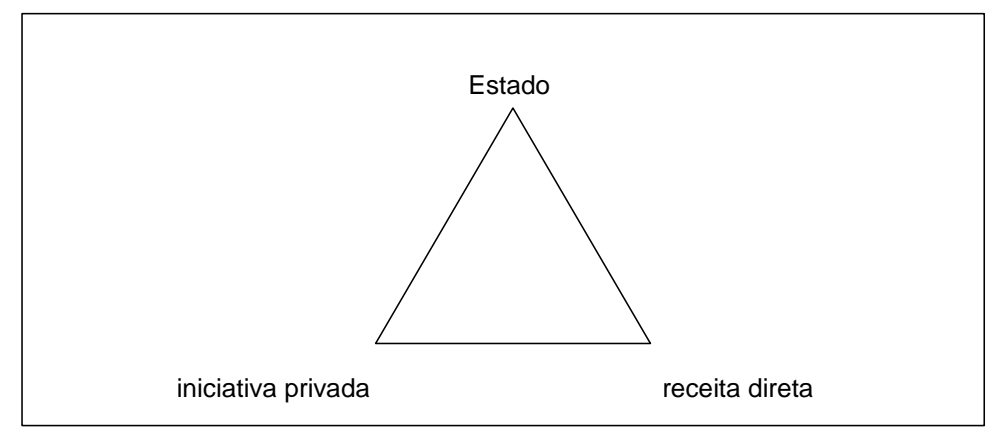

Fonte: Almeida, 1992, p. 9.

O mecenato foi a primeira forma de obtenção de recursos para a produção cultural. A expressão mecenato vem de Mecenas, ministro do imperador romano Caio Augusto, entre 30 a.C. e 10 d.C. Durante 40 anos foi o responsável pela 
aproximação do Estado Romano com os pensadores, filósofos e artistas. Mecenas criou no Império Romano, a maneira grega de se pensar o poder, para os quais é dever do Estado promover o conhecimento e as artes.

Os governantes ao promoverem as artes queriam se eternizar, entrar para a história como grandes benfeitores.

Um segundo momento surge no início do Renascimento quando aparece a figura do mecenas na Europa, principalmente na Itália, que se destacava nas navegações e conseqüente acúmulo de capital.

O terceiro momento da atuação do capital privado no suporte à cultura aparece na virada do século XX, nos Estados Unidos. O crescimento econômico advindo da transferência de capital da Inglaterra e da indústria do petróleo, da indústria automobilística e de negócios bancários, fez com que pessoas que estavam gerando suas próprias fortunas, mas não tinham prestígio social, encontrassem no apoio às artes uma forma de se legitimarem perante aquela sociedade.

A característica básica desse mecenato é que ele se fez por decisões pessoais, sem considerar a questão mercadológica.

Mas o grande motivador do mecenato contemporâneo é o incentivo tributário, permitido pela legislação americana.

Já o Estado, outra patrocinador da cultura, até o final do século XVIII caminhou paralelo à figura do mecenas. Essas duas forças se confundiam, inclusive pelas ações da Igreja. O Estado, a Igreja e as grandes famílias dividiam a estrutura e os mecanismos de poder.

A partir do século XX, o Estado figura-se isolado no poder e sua atuação na área cultural é política, ideológica e visa resultados de imagem em benefício próprio. 
No Brasil, a ação do Estado como promotor da atividade cultural começou a partir da Revolução de 30, no governo de Getúlio Vargas, por meio do Ministro da Educação e Saúde, Gustavo Capanema, que levou para o Ministério, Carlos Drummond de Andrade, Portinari, Villa-Lobos e Cecília Meireles. Havia a intenção de formular um projeto de política cultural brasileira.

Não há como pensar que a atuação do Estado na cultura não se dê de forma política. E aí está o risco de comprometer o fundamental no processo de criação, que é a liberdade.

A última forma de captação de recursos supracitada é a receita direta, ou seja, a capacidade que o projeto cultural tem de gerar recursos internamente, sem precisar do Estado ou de um mecenas. A dependência é de seu consumidor, que paga a entrada do teatro, do cinema, de um show ou compra uma obra de arte.

Essa forma de arrecadação, no Brasil, esbarra na existência de um universo restrito de consumidores culturais. Dados do IBGE informam que 5\% da população brasileira economicamente ativa e $2 \%$ da população total brasileira são consumidores regulares de cultura (Almeida, 1992, p.14).

Por esse motivo, reduzido mercado de consumidores culturais, e pelo caráter pessoal do mecenato que também está na dependência de incentivos tributários, e pela atuação do Estado que pode restringir a liberdade de criação, é que surge o marketing cultural como uma alternativa para o produtor cultural, que pode oferecer às empresas a oportunidade de um investimento. 


\subsection{LEIS DE INCENTIVO À CULTURA}

Atualmente, o mercado brasileiro conta com dispositivos legais de incentivo à cultura que estimulam as doações e patrocínios de empresas e pessoas físicas, mediante redução de impostos.

Em 1986, com a promulgação da Lei 7.505 (Lei Sarney), mais empresas passaram a patrocinar a cultura, o que acabou por gerar no mercado esse tipo de associação. Essa lei vigorou até 1990, quando o Governo Collor suprimiu os incentivos fiscais.

Já em 1991, esse mesmo Governo criou a Lei 8.313 (Lei Rouanet), e em 1993, a lei do audiovisual. Vários estados e municípios passaram a criar legislações, no âmbito dos seus impostos (ICMS, ISS, IPTU), para incentivo à cultura.

\section{Lei Federal}

Lei 8.313, de 23 de dezembro de 1991, que visa a captação de recursos com base em incentivos fiscais do Imposto de Renda, criou um conjunto de ações que foi chamado de Programa Nacional de Apoio à Cultura (PRONAC), desenvolvido por meio dos seguintes mecanismos: Fundo Nacional da Cultural (FNC); Fundos de Investimento Cultural e Artístico (FICART); Incentivo a projetos culturais.

Utilizando os incentivos, a empresa ou a pessoa física investidora deixa de recolher parte do imposto e o transfere para o projeto cultural, que é a chamada renúncia fiscal. 
Para a empresa parece, a princípio, que não há nenhuma vantagem nesses incentivos, pois continuará desembolsando o valor do imposto e que apenas mudará a sua destinação.

A empresa ao utilizar-se do projeto cultural como parte de sua estratégia de marketing tem diversas vantagens. A todas já mencionadas deve-se acrescentar a certeza de que o dinheiro do imposto será aplicado em cultura e, principalmente, que o investidor estará contribuindo de forma efetiva para o bem-estar social e para preservação do patrimônio e valores culturais da sociedade.

Os recursos do Fundo Nacional da Cultura - FNC são destinados aos projetos de natureza comunitária ou experimental que, sem o apoio do Governo, dificilmente seriam realizados por não despertarem grande interesse do investidor privado.

Os Fundos de Investimento Cultural e Artístico - FICART destina-se à captação de recursos no mercado financeiro, através da aquisição de quotas de fundos em condomínio administrados por instituições financeiras e regulamentados pela Comissão de Valores Mobiliários (CVM).

As quotas rendem juros e dividendos, mas a aquisição não é beneficiada por incentivo fiscal.

O mecanismo reconhece o caráter comercial da indústria cultural, financiando projetos que geram lucros e recompensem o investidor.

O Incentivo a Projetos Culturais consiste no apoio direto de pessoas físicas e jurídicas, através de doações ou patrocínios, a projetos culturais aprovados pelo Ministério da Cultura.

Podem candidatar-se aos benefícios da Lei pessoas físicas, empresas e instituições com ou sem fins lucrativos, de natureza cultural, e entidades públicas da 
Administração indireta, tais como Fundações, Autarquias e Institutos, desde que dotados de personalidade jurídica própria e, também, de natureza cultural.

Os projetos devem destinar-se a desenvolver as formas de expressão, os modos de criar e fazer, os processos de preservação e proteção do patrimônio cultural brasileiro, e os estudos e métodos de interpretação da realidade cultural, bem como contribuir para propiciar meios que permitam o conhecimento dos bens e valores artísticos e culturais, compreendendo, os seguintes segmentos: teatro, dança, circo, ópera, mímica, produção cinematográfica, videográfica, fotográfica, discográfica, literatura, música, artes plásticas, artes gráficas, gravuras, cartazes, filatelia, folclore, artesanato, patrimônio cultural, inclusive histórico, arquitetônico, arqueológico, bibliotecas, museus, arquivos e demais acervos, rádio e televisão, educativas e culturais, de caráter não-comercial.

O projeto deve ter temática centrada nas áreas e segmentos definidos na Lei. Do mesmo modo, o projeto deve trazer benefícios para a população. Além de incrementar a produção, a Lei se destina a democratizar o acesso da população a bens culturais. Os mecanismos que facilitem este acesso (ingressos a preços populares ou entradas gratuitas em espetáculos, distribuição de livros para bibliotecas, exposições de artes abertas, por exemplo) são fundamentais para o cumprimento dessa finalidade.

A Lei prevê que o doador ou o patrocinador poderá deduzir do imposto devido na declaração do Imposto sobre a Renda os valores efetivamente contribuídos em favor de projetos culturais aprovados de acordo com a sistemática definida na própria Lei, com base nos seguintes percentuais: pessoas físicas oitenta por cento das doações e sessenta por cento dos patrocínios; e pessoas 
jurídicas tributadas com base no lucro real - quarenta por cento das doações e trinta por cento dos patrocínios.

O valor total a ser abatido do imposto devido não pode ultrapassar a $4 \%$ do valor total no caso das pessoas jurídicas, percentual que se eleva a $6 \%$ no caso das pessoas físicas.

O patrocinador poderá, dependendo do projeto que apoiar, obter retorno em produto (livros, discos, gravuras, CD-Rom) para utilização como brinde. O recebimento de produto artístico gerado pelo projeto está limitado a $25 \%$ do total produzido e deve ser destinado à distribuição gratuita.

\subsection{RESPONSABILIDADE SOCIAL E CULTURAL}

Os cientistas sociais referem-se à cultura como o modo de vida de um povo, em toda sua extensão e complexidade (estrutura social no campo das idéias, das crenças, dos costumes, artes, linguagem, moral, direito, dentre outras), que se reflete na forma de agir, sentir e pensar de uma organização social, em constante transformação.

Dessa forma, cultura pode ser considerada como as manifestações espontâneas de um grupo social que são incorporadas ao seu modo de vida, o que o caracteriza e o distingue dos demais.

Hoje, comumente, cultura refere-se às atividades nos campos da arte, literatura, música, teatro, dança, ou qualquer outra manifestação que expresse uma forma de organização social, mantendo suas raízes, como também num permanente intercâmbio de experiências e realizações, para Muylaert; "O conceito primitivo de 
cultura, regional e caracterizante, passa a ter um sentido universal e pleno, pressuposto que leva a considerar um povo culturalmente avançado aquele que tem acesso ao conhecimento e à informação" (Muylaert, 1995, p.18).

É questionável falar em povo culturalmente avançado aquele que tem acesso ao conhecimento e à informação. De certo, uma sociedade informada tem uma melhor capacidade de questionar a sua realidade e dessa forma, ter instrumentos para tentar levar adiante as mudanças necessárias para seu progresso.

Esse pensamento, que é lógico e coerente, pode levar a um equívoco, quanto à inexistência de cultura no segmento marginalizado da sociedade. O que ocorre é o sufocamento das manifestações culturais daquele povo, que, por estarem socialmente excluídos, não são capazes de aflorarem seu conhecimento, para Almeida; "A cultura enquanto experimento pesquisa a linguagem, flerta com o novo, discute o estabelecido, subverte e choca" (Almeida, 1994, p. 29).

Quando é dado meios de produção e condições de acesso à população socialmente marginalizada à manifestações culturais, essa se mostra capaz de produzir e integrar-se àquele movimento.

No âmbito da indústria cultural, a noção é de produto e a estratégia de mercado. Um disco é igual a uma caneta que é igual a um sapato que é igual a um livro.

O grande desafio do turismo cultural é tratar a ação cultural como um meio de atingir os objetivos traçados no planejamento estratégico do município e ao mesmo tempo, o respeito à liberdade da manifestação artística e possibilitar o acesso de boa parte da população, bem como promover o acesso de turistas à região. 
O capítulo a seguir trata da importância do espaço cultural como atrativo turístico. 


\section{O ESPAÇO CULTURAL COMO ATRATIVO TURÍSTICO}

O espaço cultural como atrativo turístico é motivado pela busca de informações, de conhecimentos culturais e regionais, de interação com outras pessoas, comunidades e lugares, onde a curiosidade cultural é aguçada, tem-se curiosidade sobre os costumes, da tradição e da identidade cultural. A cultura como motivadora do turismo tem como fundamento o elo entre o passado e o presente, o contato e a convivência com o legado cultural e, também, com as tradições que foram influenciadas pelo tempo, mas que permaneceram intactas devido à cultura.

O espaço cultural como atrativo turístico abre perspectivas para a revitalização e valorização do patrimônio regional, do revigoramento das tradições, da descoberta da cultura de determinada região como patrimônio de bens culturais, materiais e imateriais, em muitos casos ofuscados pela modernidade.

Neste aspecto, o espaço cultural como atrativo turístico passa determinantemente pela questão da cultura local e regional. Valoriza o resgate dos valores culturais, reforça a necessidade de compreender às particularidades culturais daquela região e incentiva a participação social.

O espaço turístico proporciona a revitalização da identidade cultural, da preservação dos bens culturais e das tradições locais. Além disso, geram mecanismos de sustentabilidade e espaços propícios às expressões culturais.

O turismo cultural pode ser considerado típico, pois acontece de forma diversificada dos outros tipos de turismo e, geralmente, não possui características como permanência, lazer, etc., as características do turismo cultural não se expressam pela viagem propriamente, mas sim, pela cultura de determinada região. 
O complexo arquitetônico do espaço cultural 508 sul, foco do presente estudo, está situado na W3 sul, que já foi o centro nervoso da cidade, um verdadeiro boulevard que atraía as pessoas com suas vitrines e letreiros decorados, onde acontecia o carnaval de rua, e as pessoas se encontravam em seus bares e restaurantes. Tudo isso hoje é memória lembrada apenas pela geração pioneira.

O contexto atual da via,é de aparente decadência, a "baixa auto-estima" da avenida se deve à falta de áreas de lazer, escassez de locais de animação urbana e espaços públicos ou privados de permanência e convívio.

Existem vários estudos e propostas para revitalização da W3 sul, todas com foco na requalificação da via com objetivo de reforçar as potencialidades de uso misto. Uma das mais importantes propostas é que transforma alguns trechos da avenida em corrredor cultural -Trata-se de um grupo destacado de edificações a serem objeto de projetos particulares e públicos, e que abrigariam grandes instituições na área das artes e da cultura em geral - e neste contexto de revitalização da W3 que o espaço 508 sul deve focar suas ações e eventos.

O espaço tem todas as vantagens para ser um marco na revitalização da via W3 sul, com estrutura para abrigar eventos e exposições abrangendo desde a dança e o teatro além de artes plásticas, oficinas de arte e até cinema.

Apesar de toda esta estrutura o espaço cultural 508 sul não é reconhecido pela população local como um espaço atuante e representativo.

Uma política de eventos utilizando os meios existentes como as Leis de Incentivo à Cultura e uma gestão baseada no marketing cultural deve ser implementada para que o espaço cultural se firme como atrativo cultural e turístico. 
Figura 4: Foto do Espaço Cultural 508 Sul

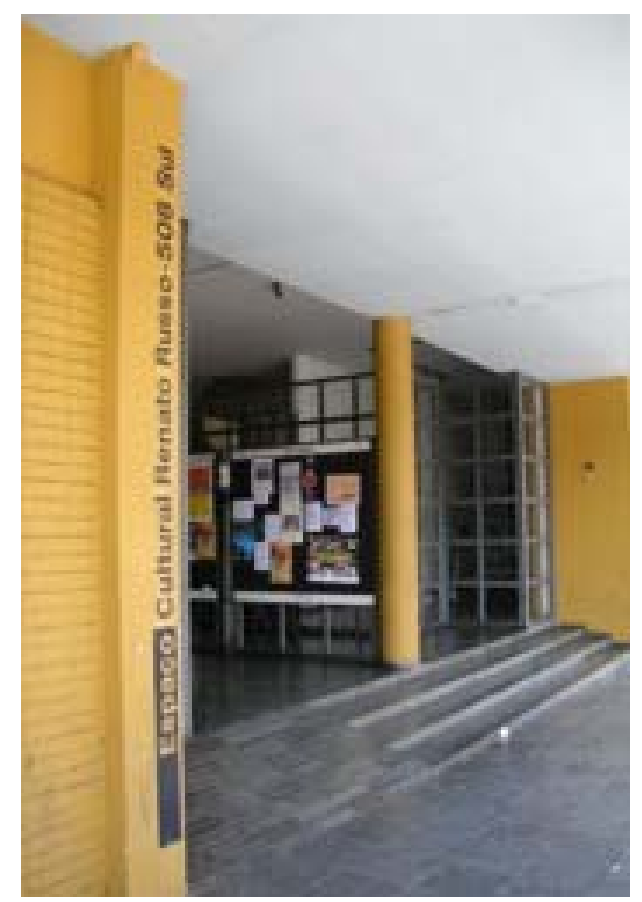

Fonte: http://www.sc.df.gov.br, 2007.

O primeiro edifício que deu origem ao complexo cultural que começou a se estabelecer na década de 70 situava-se num setor destinado ao comércio, com galpões de estocagem de materiais de um lado, pela W2, e área de comércio, atendimento e administração voltada para a W3.

Nesse período, a sede da Fundação Cultural do Distrito Federal (FCDF) era em um dos galpões da 508 Sul. A história do espaço tem início com a ocupação dos galpões por artistas e assessores da FCDF, então sob a direção de Ruy Pereira da Silva.

A FCDF lutou junto à prefeitura do Distrito Federal para incorporar parte do bloco "A" da 508, que então funcionava como seção da Secretaria de Finanças. Nesse espaço, voltadas para a W3, foram instaladas as primeiras galerias. A 
primeira abre em 1973, com exposição do arquiteto japonês de renome internacional Kenzo Tange.

As galerias B e C são abertas em seguida, e alguns atores começam a ensaiar nessas dependências nas horas vagas. Alguns notam que o galpão da esquina seria ideal para um centro de oficinas e laboratórios. Importantes exposições passam a ser programadas na 508.

A 508 passa por momentos difíceis, até que em 1986 toda a comunidade mobiliza-se para a retomada. O arquiteto Antonio Eustáquio é chamado para repensar o espaço e propõe a fusão dos galpões e a abertura das paredes, possibilitando uma passagem da W2 para a W3.

Em 1993, o Espaço Cultural 508 Sul é reinaugurado, depois de quase quatro anos em obras, com verba da fundação japonesa Mokiti Okada.

Atualmente é composto pelo Teatro Galpão, sala multiuso, sala de vídeo, sala para cinema, galpão destinado a oficinas, biblioteca, mezanino e espaço para laboratório e escritórios de administração.

O Espaço Cultural 508 Sul possui os seguintes espaços (anexos 1 e 2):
a) Praça central;
b) Teatro Galpão;
c) Sala Multiuso;
d) Sala Marco Antônio Guimarães;
e) Teatro de Bolso;
f) Galeria Rubem Valentim;
g) Galeria Darlan Rosa;
h) Galeria Parangolé;
i) Mezanino da Biblioteca; 
j) Sala Vitrine;

k) Sala Alternativa/Laboratório de Fotografia;

l) Gibiteca;

m) Musiteca;

n) Biblioteca de Artes Ethel de Oliveira Dornas;

o) Galpão das Artes;

p) Estúdio de Som.

A praça central é o espaço ideal para exposições, lançamentos, feiras, performances e encontros. Arejada e iluminada, tem duas entradas, pela W2 e pela W3, e dá acesso às galerias e salas do Espaço Cultural 508 Sul. Na Praça Central, encontram-se a Galeria Darlan Rosa, Café da 508, bilheteria, sala de informações e mezanino da Gibiteca.

O Teatro Galpão surgiu em 1974, a partir de dois galpões que funcionavam como depósito, por iniciativa de João Antônio, então assessor de teatro da Fundação Cultural. Projetado pelo arquiteto Mauro Bonde, da UnB, o espaço foi construído em um mês. $O$ teatro de arena teve sua estréia com "O Homem que Enganou o Diabo e ainda Pediu o Troco", de Luiz Gutemberg. A peça reuniu grande elenco de atores profissionais e amadores da cidade, com sucesso de público e crítica. O teatro amador de Brasília, na época bastante efervescente, encontrou no espaço seu pouso ideal. As estréias sucederam-se com seqüência impressionante até para os dias de hoje, revelando nomes de diretores e atores como Augusto Pontes, Dácio Lima, Gê Martu, Humberto Pedrancini, Hugo Rodas e Ricardo Torres.

A sala multiuso tem capacidade para 180 pessoas, destinada a espetáculos e ensaios de dança e teatro, conferências e performances. 
A Sala Marco Antônio Guimarães possui 140 lugares e palco italiano, destina-se à exibição de filmes e montagens de shows e teatro. A curvatura do teto se ajusta às corretas necessidades de acústica, proporcionando a projeção perfeita da voz de atores e cantores.

O Teatro de bolso destina-se a mostras de vídeo, palestras, projeção de slides, leituras dramáticas, debates, seminários e ensaios cênicos. Tem capacidade para 66 pessoas, com poltronas não-numeradas e palco curvo em tábua corrida. Não dispõe de urdimento, coxia, iluminação cênica e sonorização. Funciona das 9h às $23 h 45$.

A Sala Alternativa / Estúdio de Fotografia destina-se a reuniões, cursos, encontros, oficinas e ensaios cênicos. Tem área de 25 metros quadrados. Funciona das $9 \mathrm{~h}$ às $21 \mathrm{~h}$.

O Estúdio de Som destina-se a ensaios musicais, tem área de 25 metros quadrados com cabine de som e forração acústica em carpete. Não dispõe de sonorização e iluminação cênica. Funciona das 9h às 21h.

O Espaço Cultural 508 Sul possui exposições durante todo o ano. Suas galerias têm história e a cada temporada levam um público numeroso e interessado para as exposições coletivas e individuais dos artistas locais, de outros artistas brasileiros e também de nomes internacionais seja da pintura, da fotografia ou da performance (anexo 3).

O Espaço Cultural 508 Sul oferece à comunidade o 'Cinema no Espaço', considerado uma nova opção de lazer para a comunidade. Para tanto, viabiliza a apresentação de filmes longas-metragens das $12 \mathrm{~h}$ às $14 \mathrm{~h}$, uma vez por semana (anexo 3). 
Além disso, existe o projeto da criação de um novo espaço de lazer e cultura dentro da 508 Sul, que oferecerá à comunidade local a oportunidade de apreciar a cultura de outros países, através de mostras diárias de vídeos e longa metragem.

Existe, ainda, o projeto Escola de Música no Espaço, desenvolvido em parceria com a Escola de Música de Brasília (EMB), vinculada à Secretaria de Educação, o projeto Escola no Espaço oferece à comunidade programação musical de qualidade, com pequenos concertos, recitais e shows produzidos por grupos, instrumentistas e formações musicais diversas entre os alunos e professores da EMB. Os shows têm entrada gratuita e acontecem na Praça Central da 508 Sul.

Como podemos observar na descrição das atividades do Espaço Cultural 508 Sul é de suma importância, a valorização dos eventos que valorizam a arte como: espetáculos de dança, música, teatro, mostras e festivais. Mas para que o público participe de tais atividades é preciso que haja uma ação educativa, no sentido de atrair a comunidade para o Espaço Cultural. Tais ações educativas estão direcionadas para os seguintes aspectos:
a) a interatividade do público com a arte;
b) a sensibilização para a arte;
c) a compreensão e a internalização do valor artístico da obra;
d) a familiarização com toda obra do autor; e
e) a criação de afeto e cumplicidade com a arte.

Os eventos voltados para a arte tornam-se, portanto, um serviço educativo com foco na arte e sua concepção. Os eventos culturais do Espaço Cultural 508 Sul têm como objetivo informar e sensibilizar o público para a cultura. De uma visão eventista, com predomínio da cultura do entretenimento, para uma visão holística, 
socioeducativa-cultural do evento, em que predominam ações de educação, socialização e de formação e aperfeiçoamento para o exercício da cidadania. 


\section{CONCLUSÃO}

Com a elaboração do presente estudo concluímos que o turismo cultural é uma alternativa para diversas cidades do mundo. Mas, também pode ser uma opção para diversas cidades brasileiras que possuem um grande patrimônio cultural.

O Espaço Cultural 508 Sul, foco do presente estudo, pode ser considerado um atrativo cultural, que privilegia a comunidade local com eventos culturais. Devido aos diversos eventos culturais apresentados pelo Espaço este pode ser considerado um atrativo cultural do Distrito Federal.

Como vimos, existem várias formas de incentivo à produção cultural mediante a promoção de eventos culturais, como os realizados no Espaço Cultural 508 Sul.

A primeira forma de incentivo a ser considerada é a realização de eventos do tipo exposições, concursos e salões. Tais eventos têm como objetivo estimular a produção cultural, em especial dentre os artistas mais jovens e em processo de formação.

A segunda forma observada no estudo refere-se à realização de projetos de revitalização do Espaço Cultural 508 Sul, transformando-o em agente promotor de eventos culturais.

Estas ações visam alavancar a produção cultural e tornar o Espaço Cultural 508 Sul um agente de desenvolvimento e preservação do patrimônio cultural.

Como se pode notar, a realização de eventos culturais é de suma importância para atrair a comunidade para dentro do Espaço Cultural. O que torna o evento cultural um agente do patrimônio histórico-cultural.

Tal categorização faz do evento cultural muito mais do que um simples 
acontecimento, mas algo de fundamental importância para a definição do estilo do povo e da identidade da própria cidade onde ele se realiza. Portanto, o evento cultural, quando vem sucedido, faz história e torna-se parte da memória da cidade. É o que lhe garante a condição de patrimônio cultural da cidade.

No âmbito da cultura, o evento não pode ser visto apenas como uma estratégia de entretenimento, de mídia, de negócios e de promoção turística e cultural. Trata-se da mais nova tendência de democratização da cultura e das artes em geral e da promoção da cidadania individual e coletiva. Instrumento que é bem aproveitado pelo Espaço Cultural 508 Sul. 


\section{REFERÊNCIAS}

ALMEIDA, Candido José Mendes de. A Arte é Capital. Rio de Janeiro: Rocco, 1994.

ALMEIDA, Candido José Mendes de; DA-RIN, Silvio. Marketing Cultural ao Vivo Depoimentos. Rio de Janeiro: Francisco Alves, 1992.

ANDRADE, José Vicente. Turismo - fundamentos e dimensões. São Paulo: Editora Ática, 2003.

BENI, Mário Carlos. Análise estrutural do turismo. São Paulo: Editora SENAC, 2003.

EMBRATUR, 2000 In: ROMANINI, Vinicius; UMEDA, Marjorie. Esportes de aventura ao seu alcance. São Paulo: Bei Comunicação, 2002.

FUNARI, Pedro Paulo; PINSKY, Jaime. Turismo e patrimônio cultural. São Paulo: Contexto, 2005.

GOMES, Denise Maria Cavalvanti. Turismo e museus: um potencial a explorar. In:FUNARI, Pedro Paulo; PINSKY, Jaime. Turismo e patrimônio cultural. São Paulo: Contexto, 2005.

LAKATOS, Eva Maria; MARCONI, Marina de Andrade. Metodologia científica. São Paulo: Atlas, 2004.

LEITE, José Romero Rodrigues. Turismo e segurança. 2 ed. Pernambuco: EMPETUR, 1987.

MELO NETO, Francisco Paulo de. Evento: da ação, de entretenimento a agente de promoção do patrimônio histórico-cultural. In: FUNARI, Pedro Paulo; PINSKY, Jaime. Turismo e patrimônio cultural. São Paulo: Contexto, 2005. 
MUYLAERT, Roberto. Marketing Cultural - Comunicação Dirigida. 4. ed. São Paulo: Globo, 1995.

OTM, 2000 In: ANDRADE, José Vicente. Turismo - fundamentos e dimensões. São Paulo: Editora Ática, 2003.

RODRIGUES, Marly. Preservar e consumir: o patrimônio histórico e o turismo. In: FUNARI, Pedro Paulo; PINSKY, Jaime. Turismo e patrimônio cultural. São Paulo: Contexto, 2005.

ROMANINI, Vinicius; UMEDA, Marjorie. Esportes de aventura ao seu alcance. São Paulo: Bei Comunicação, 2002. 
ANEXO 1: MAPAS DO ESPAÇO CULTURAL 508 SUL

MAPA DA PLANTA - TÉRREO

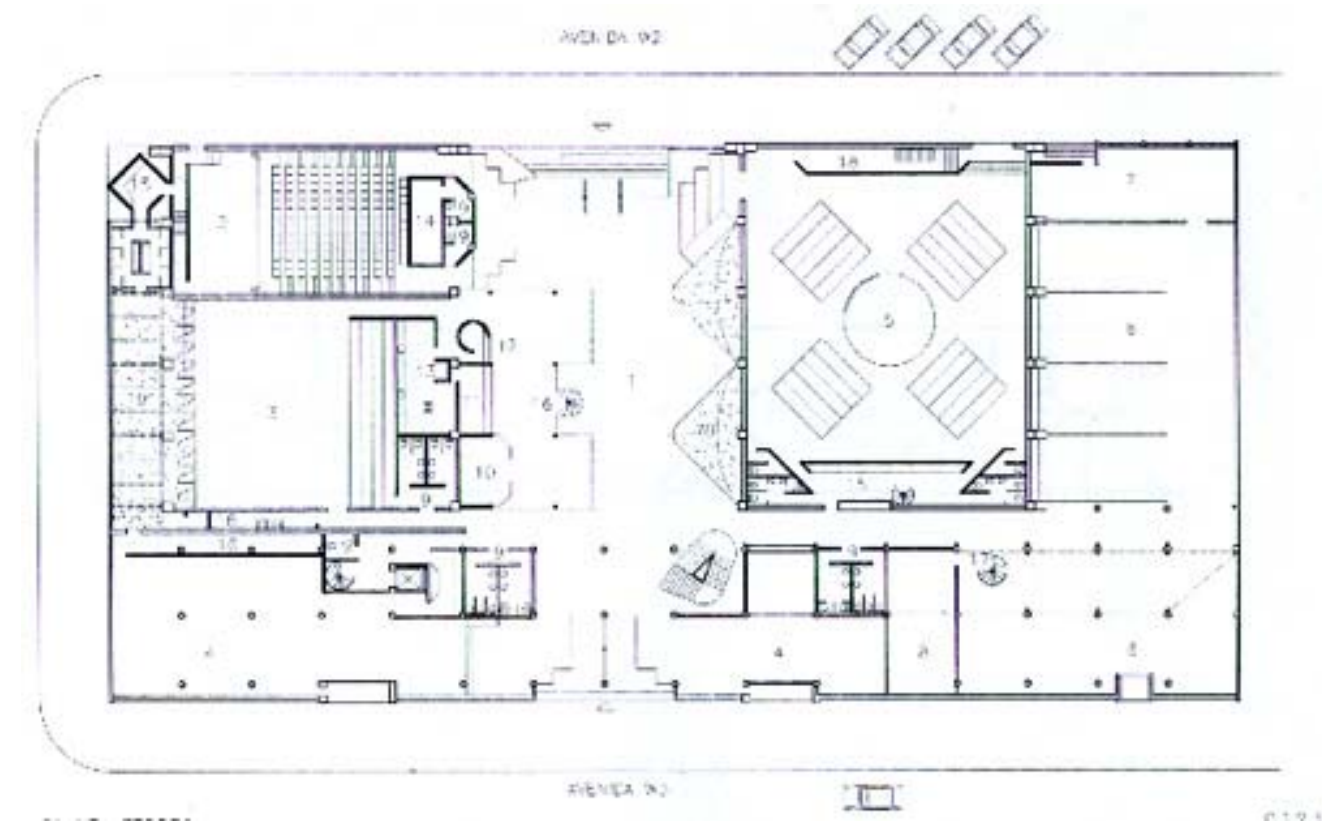

MAPA DA PLANTA - SUPERIOR

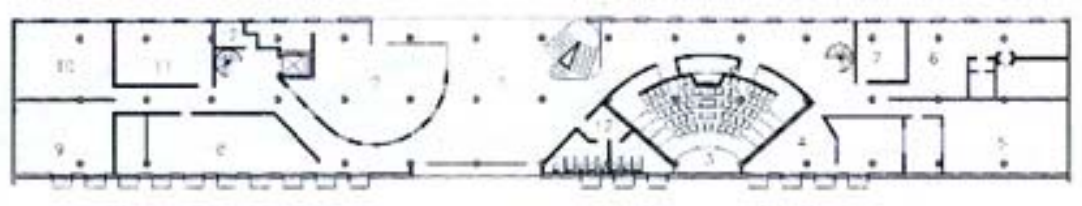


MAPA DA PLANTA - CORTE

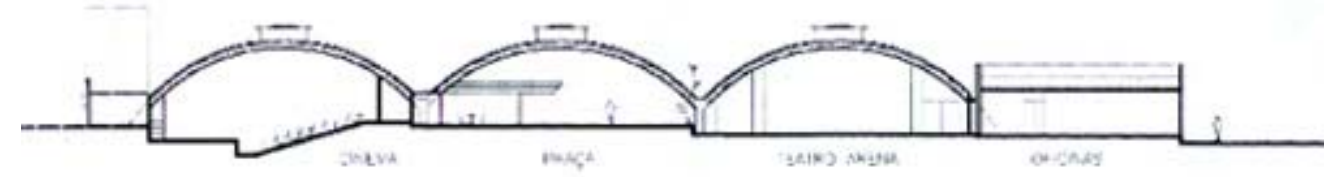

cots:

MAPA DA PLANTA - VISTA DA AVENIDA W3

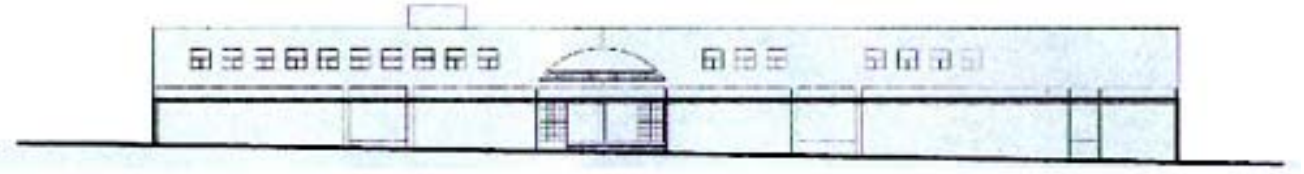


MAPA DA PLANTA - VISTA DA AVENIDA W2

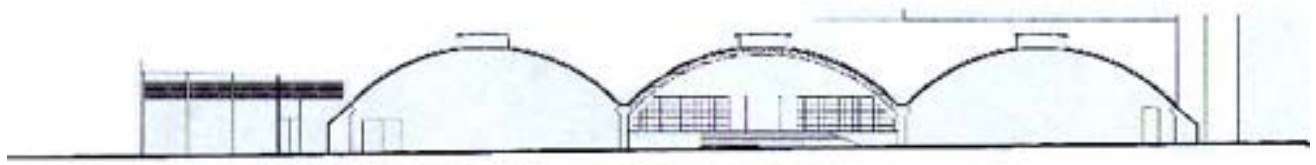

MAPA DA PLANTA - VISTA NORTE

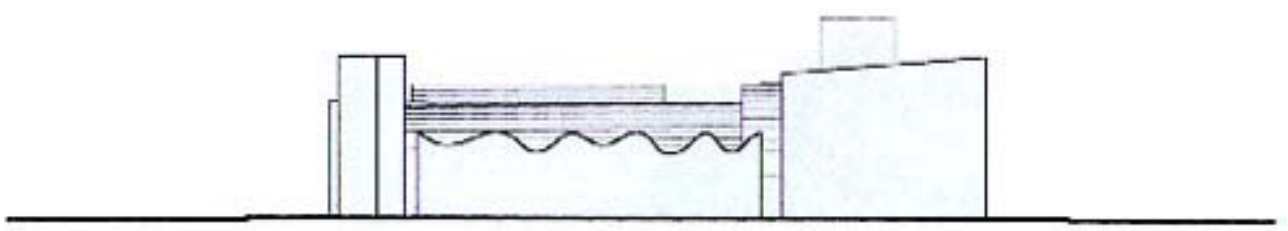


ANEXO 2: ESPAÇOS DO ESPAÇO CULTURAL 508 SUL

1. Praça Central

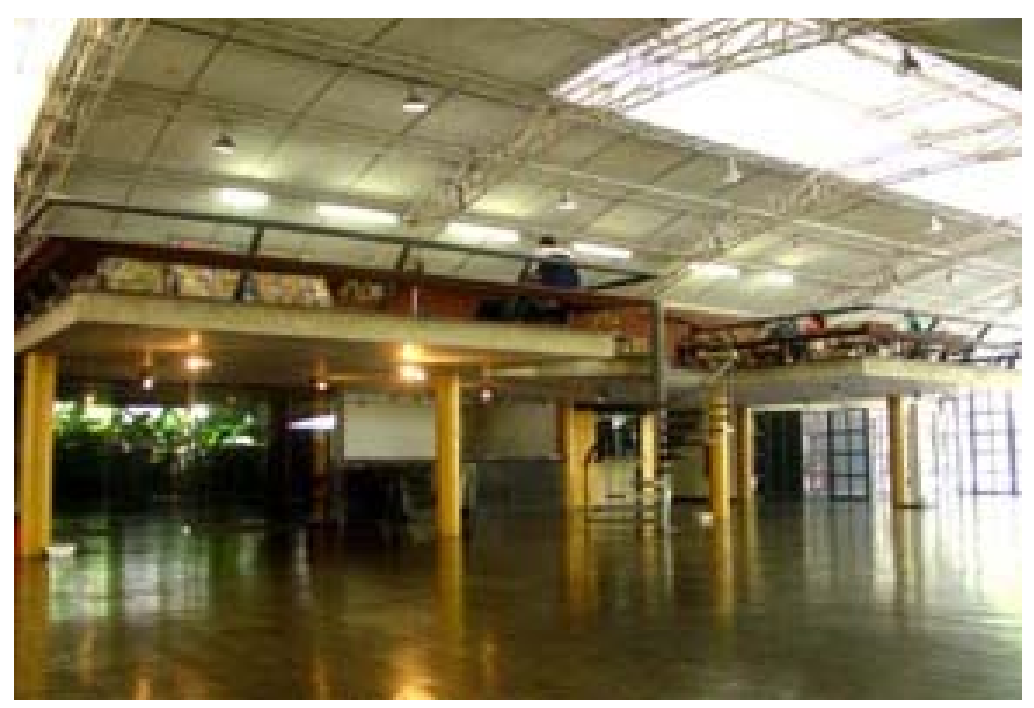

2. Teatro Galpão

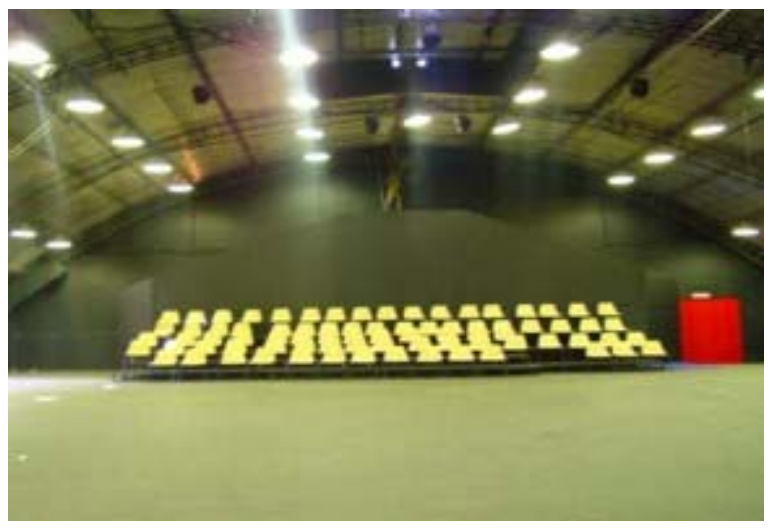


3. Sala Multiuso

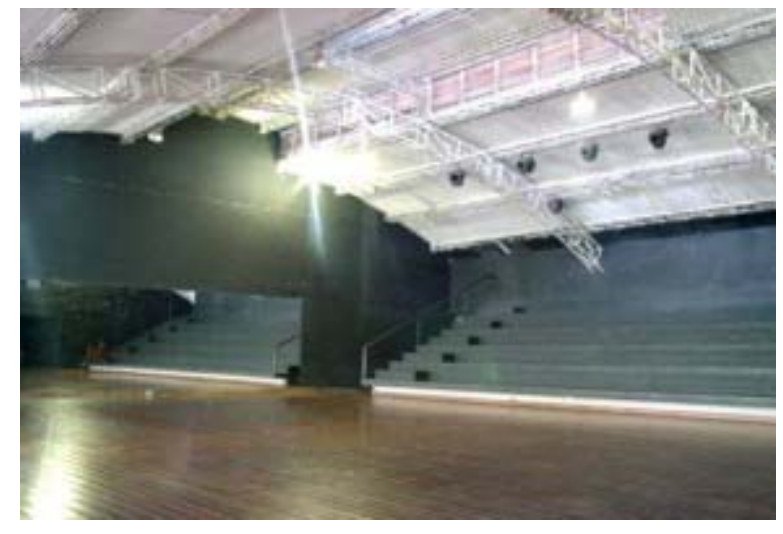

4. Sala Marco Antônio Guimarães

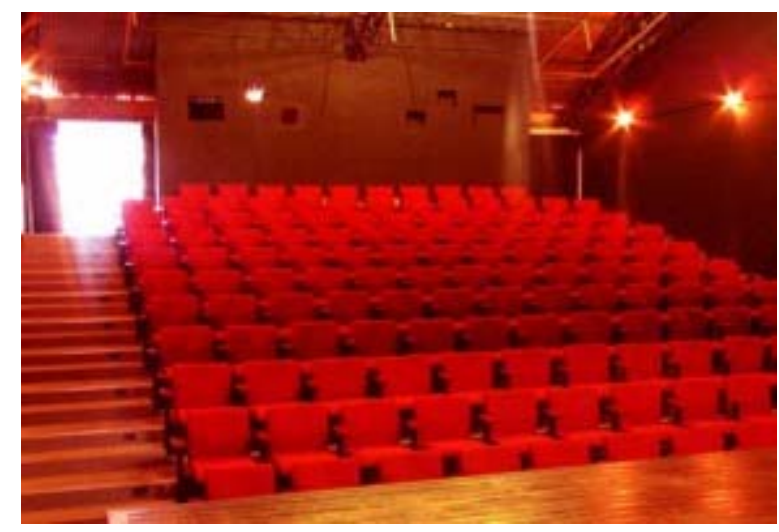

5. Teatro de Bolso

6. Galeria Rubem Valentim

7. Galeria Darlan Rosa

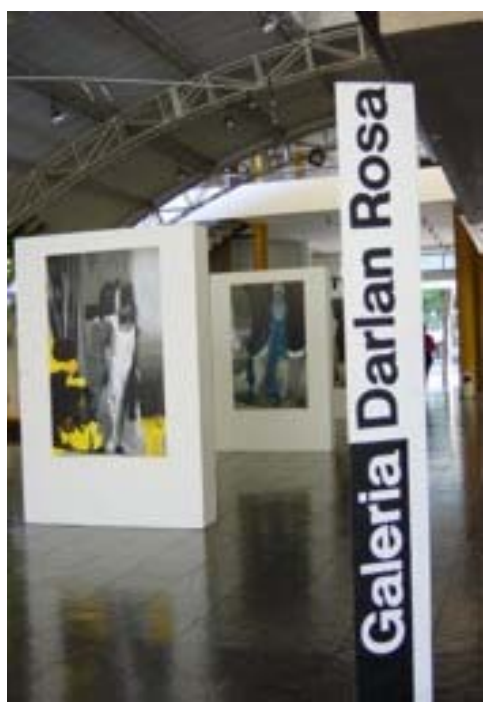


8. Galeria Parangolé

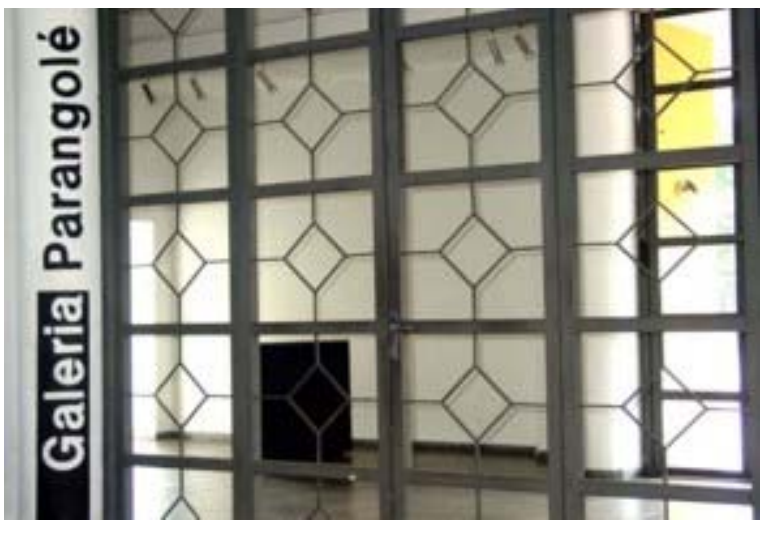

9. Mezanino da Biblioteca

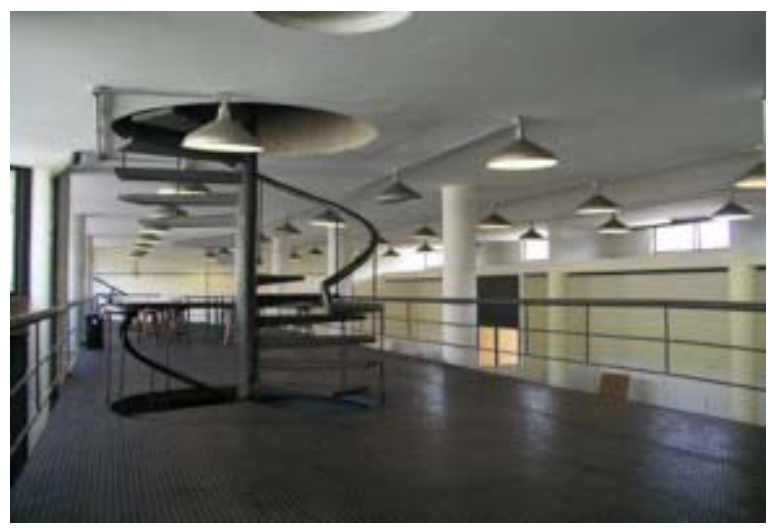

10. Sala Vitrine

11. Sala Alternativa/Laboratório de Fotografia

12. Gibiteca

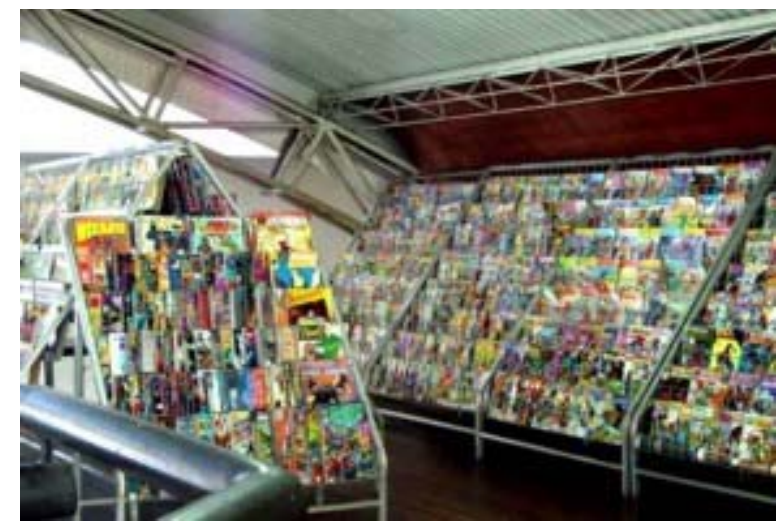

13. Musiteca 
14. Biblioteca de Artes Ethel de Oliveira Dornas

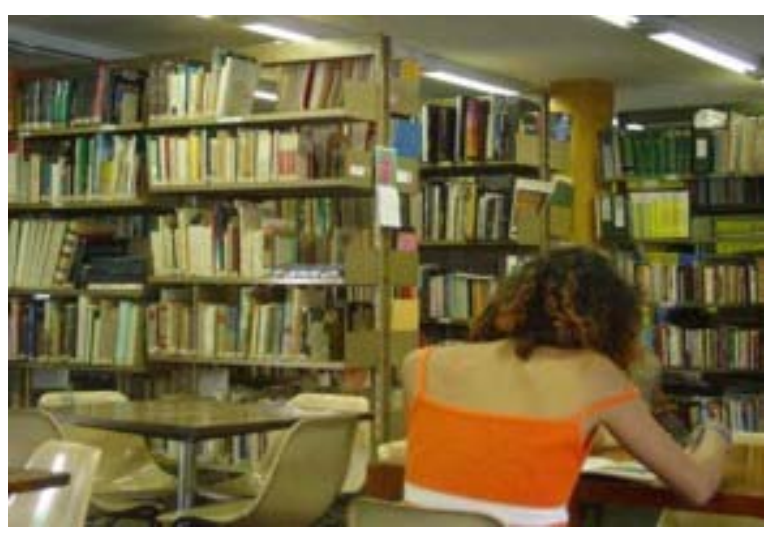

15. Galpão das Artes

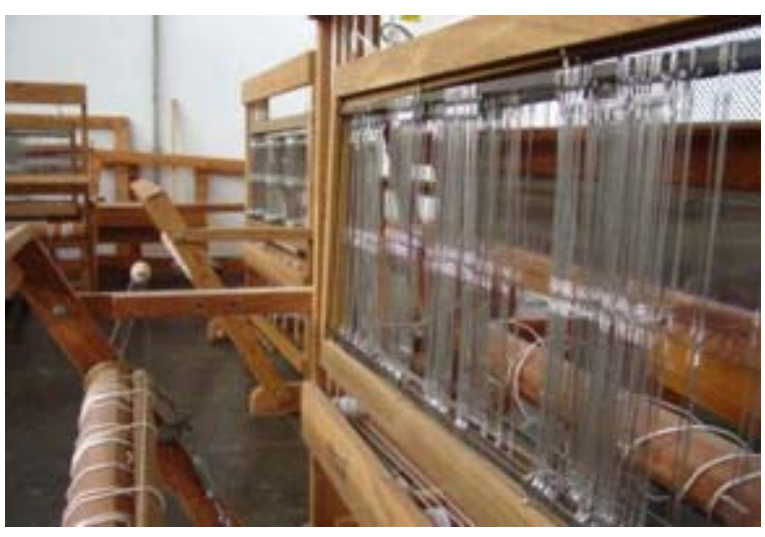

16. Estúdio de Som 
ANEXO 3: EVENTOS DO ESPAÇO CULTURAL 508 SUL

Galeria Rubem Valentim

Com área de 240 metros quadrado, é a maior galeria do espaço. O nome foi sugerido pelo artista plástico Wagner Barja, que também deu nome à Galeria Parangolé, inspirado em Hélio Oiticica.

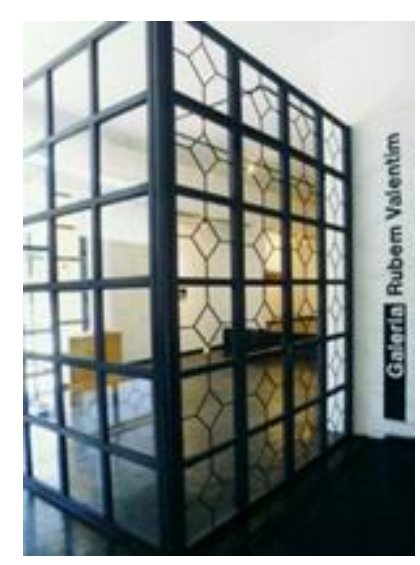

Galeria Parangolé

Tem área de 115 metros quadrados, com vitrine voltada para a W3 Sul, e fica ao lado da Galeria Rubem Valentim. Ótima para pequenas exposições.

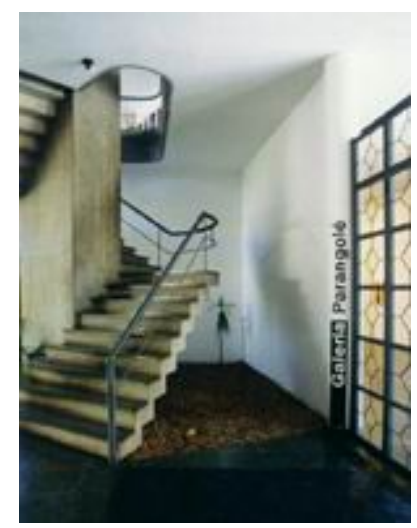




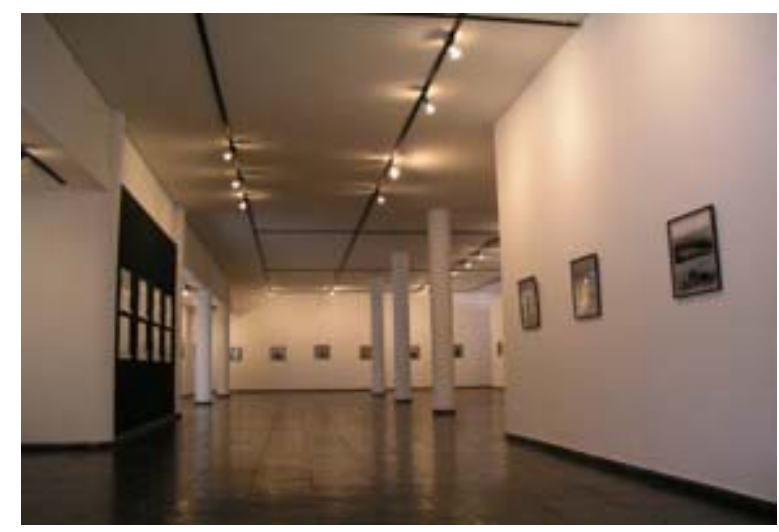

\section{Galeria Darlan Rosa}

Localiza-se na Praça Central e homenageia um dos primeiros animadores de programa infantil na televisão brasiliense, o Titio Darlan, que atualmente é desenhista, pintor e escultor. No espaço, montam-se exposições de desenhos, gravuras e fotos.

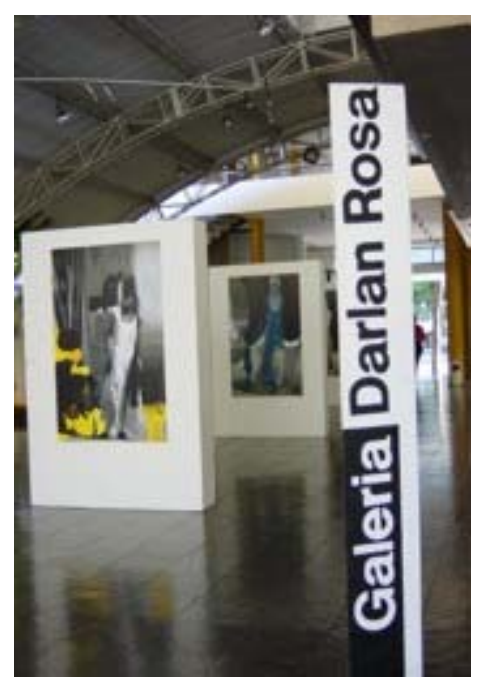

Mezanino da Biblioteca

Com área de 136 metros quadrados, destina-se a saraus, performances e lançamento de livros. Funciona das $9 \mathrm{~h}$ às $21 \mathrm{~h}$. 


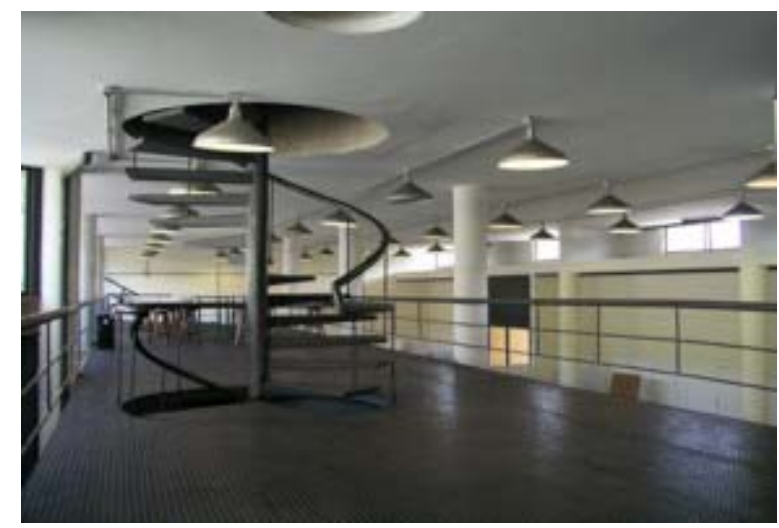

Galpão

O Galpão das Artes tem espaço físico de $1.020 \mathrm{~m}^{2}$, pias em inox de quatro metros e meio, tanques, mezanino para mesas de aula ou reuniões e instrumentos.

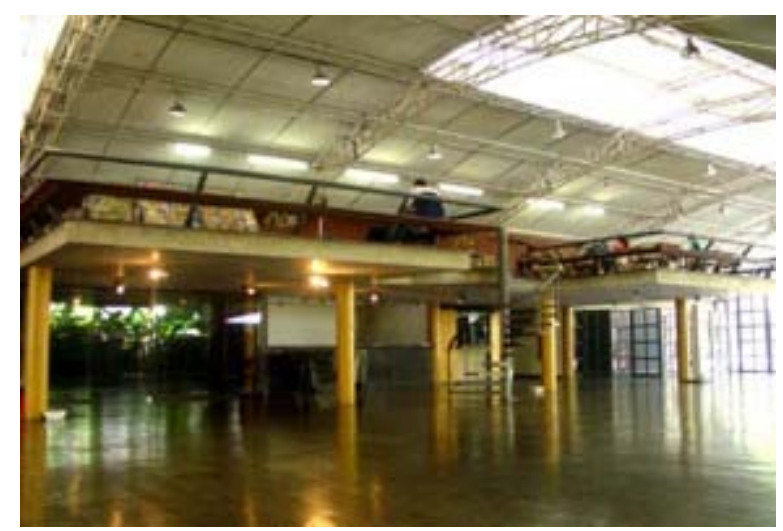

Com o amplo espaço para oficinas, aulas práticas e ateliês de artes, passou a realizar o que nos anos 70 era de responsabilidade do Centro de Criatividade.

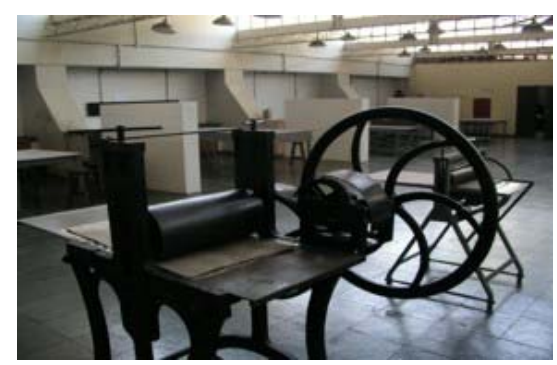

De xilogravura a desenho para história em quadrinhos, de pintura em encáustica à confecção de máscaras, de tudo um pouco se pode aprender e aprimorar no Galpão das Artes. 


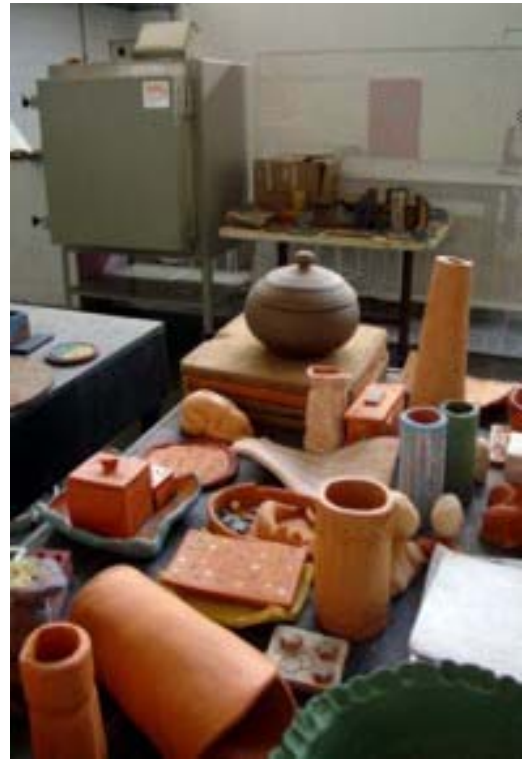

A maioria dos cursos tem inscrições gratuitas. Os professores são da Secretaria de Educação do GDF, especialistas e artistas profissionais. Algumas oficinas ocorrem como contrapartidas das exposições realizadas nas galerias do Espaço.

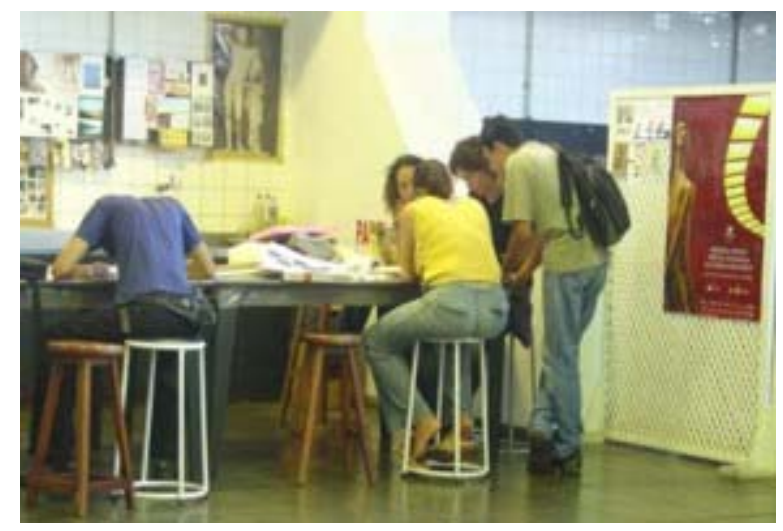


Biblioteca de Artes Ethel de Oliveira Dornas

Localizada no primeiro pavimento e especializada em livros de arte, tem três mil volumes e começou com acervo organizado nos anos 70 e 80, na Fundação Cultural do Distrito Federal, pela bibliotecária Ethel Dornas.

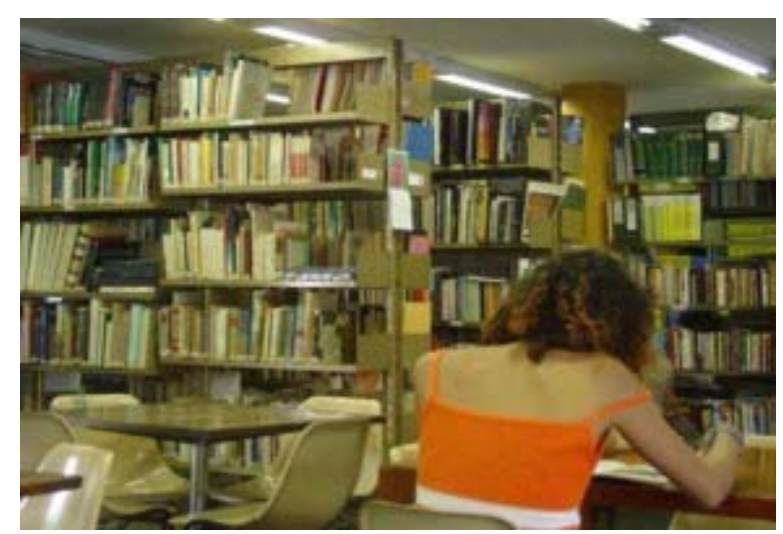

Destaque para a coleção de vídeos da NBR Galeria; originais do Hino de Brasília, composto por Neusa França; revistas independentes; e banco de textos teatrais com mais de 400 peças.

Visitação de segunda a sexta-feira, das $10 \mathrm{~h}$ às $12 \mathrm{~h}$ e das $13 \mathrm{~h}$ às $19 \mathrm{~h}$.

\section{Gibiteca}

Localizada no mezanino da Praça Central, a gibiteca tem acervo de três mil exemplares, contando com coleção de mangás, quadrinhos nacionais e internacionais, revistas de arte nacionais e internacionais, vídeo e desenhos animados, pôsteres e pranchas de ilustração, fanzines de todo o Brasil e livros de arte sobre fotografia e desenho.

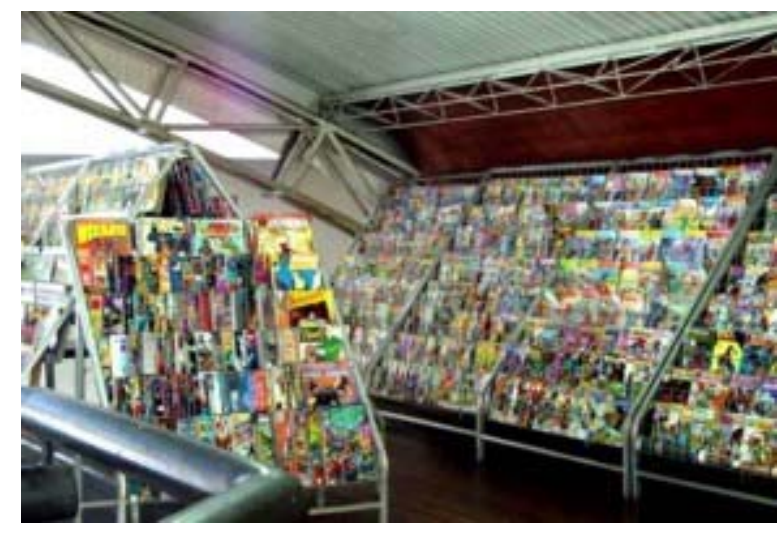

A Gibiteca tem eventos, cursos e exposições próprios. 


\section{Musiteca}

Localizada no térreo, possui acervo de aproximadamente 5 mil exemplares (CD e vinil) para pesquisa e consulta, recebendo mensalmente cerca de 1.000 freqüentadores, de segunda a sexta-feira, das $9 \mathrm{~h}$ às $18 \mathrm{~h}$.

\section{Cinema Espaço}

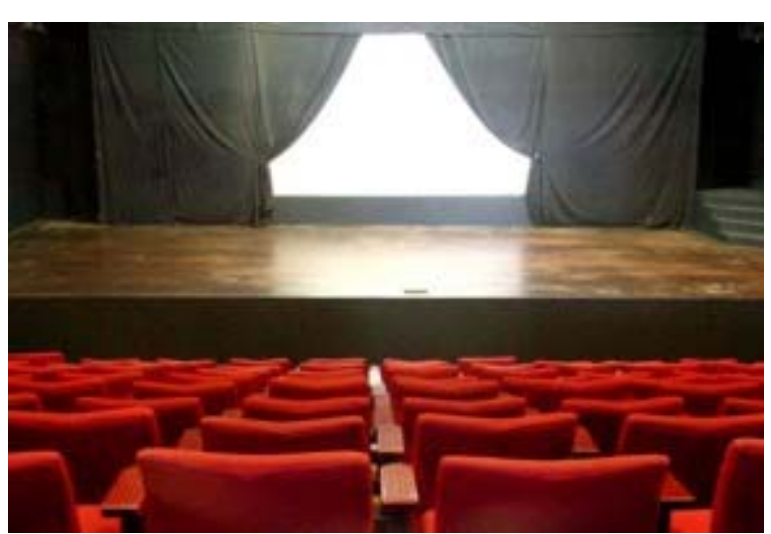




\section{ANEXO 4: NOMES QUE DEFINEM O ESPAÇO CULTURAL 508 SUL}

\section{Rubem Valentim}

Nascido no mesmo ano da Semana de Arte Moderna, em 1922, o baiano de Salvador Rubem Valentim foi um autodidata que não tardou a se tornar mestre. Construtivista, ritualista, luminoso, causou impacto nas bienais de São Paulo e Veneza. Morou em Roma e residiu vários anos em Brasília, onde foi artista influente e polêmico.

Vários espaços da cidade apresentam a marca de Rubem Valentim em painéis, esculturas e quadros. Faleceu em 1991, em São Paulo.

\section{Parangolé}

Gíria carioca dos morros na década de 50. Ganhou notoriedade no mundo das artes com o artista plástico Hélio Oiticica. Inicialmente eram esculturas móveis ou simplesmente tecidos com os quais o artista fazia composições em modelos populares.

O Parangolé número 1, que deu origem a uma série, é uma peça em lamê prateado, confeccionada com gaze e outros materiais, no jeito de corpo da malandragem carioca, hoje brasileira. Os parangolés são bandeiras tupinambás de atual e universal antropofagia.

\section{Marco Antônio Guimarães}

Curador de cinema, pesquisador e poeta, Marco Antônio Guimarães, mineiro de Abaeté, trabalhou muitos anos na Fundação Cultural do Distrito Federal, onde foi um dos principais responsáveis pelo Festival de Brasília do Cinema Brasileiro e organizador do Encontro Nacional de Escritores, além de programador do Cine Brasília.

Trabalhou na pesquisa da série "Os Pioneiros", de Tânia Quaresma, para a TV Nacional. Marco Antônio publicou o livro de poemas "Espaços: no Jardim", em 1973, e deixou inédito "Jejuns do Coração", também de poemas. Faleceu em 1995. 


\section{Darlan Rosa}

Nasceu em Coromandel, Minas Gerais. Mora e trabalha em Brasília desde 1967. Artista multimídia, Darlan atuou na televisão como produtor, diretor e apresentador de programas infantis, na TV Brasília.

Titio Darlan contava e desenhava histórias. Ilustrou vários livros infantis, publicados no Brasil, Japão e Inglaterra; e criou, para o Unicef do Brasil, o Zé Gotinha.

Darlan é também artista plástico reconhecido, com exposições por vários países. Entre suas exposições destaca-se série de esculturas em metal.

\section{Ethel Dornas}

Mineira de Araxá, nascida em 1922, Ethel Dornas veio para Brasília acompanhando o marido, Francisco Colen Dornas, funcionário da Novacap.

Pioneira, formou-se em Biblioteconomia pela UnB e ingressou na Fundação Cultural em 1962, onde atuou até 1993, quando se aposentou.

Na Biblioteca da Fundação, leitora incansável, conheceu profundamente a história de Brasília e sua cultura. Cada consulta era respondida com atenção. Ninguém ficava sem resposta. Se não tinha explicação, pesquisava até obter resultado satisfatório.

Por isso, Tia Ethel tornou-se símbolo de informação e dedicação. 